\title{
Growth Performance and Adaptive Strategy of Early Seedlings of Three Savanna Woody Species in Pots as Feedback to the Soil of Macrotermes Subhyalinus Mound
}

\begin{abstract}
Saran Traore,
Université Nazi Boni, Unité de Formation et de Recherche en Sciences et Techniques, Laboratoire d'Etude et de Recherche en Fertilité de sols, BoboDioulasso, Université Joseph Ki-Zerbo, Laboratoire de Biologie et Ecologie

Végétales, Ouagadougou, Burkina Faso

\section{Pascal Jouquet,}

Institute of Ecology and Environmental Sciences, Institute of Research for Development Bondy, France
\end{abstract}

\begin{abstract}
Heterogeneous physiognomy and observed diversity of woody vegetation in savanna are considered as specific responses of seedling species during their growth to the given site characteristics changeable with time. Consequently, understanding early plant attitude using different growth soil is an important indicator in choosing species to introduce or to assist natural or artificial regeneration to the extent that establishment and productivity of plant species are not solely controlled by the effects of habitat modification and/or environmental resource availability but mostly by seedling quality. This study focused on comparative assessment of growth performance and adaptive traits of early seedlings of Balanites aegyptiaca, Diospyros mespiliformis and Tamarindus indica three multipurpose species between of Macrotermes subhyalinus mound and surrounding area in order to understand the attitudes of woody species hosted by termite mounds. Seedlings of similar age per species were grown in plastic bags as pots containing composite soils sampled till a depth of $30 \mathrm{~cm}$ on mounds and surrounding area in Tiogo state forest and of which the amount of retained water, carbon $(\mathrm{C})$, nitrogen $(\mathrm{N})$, calcium $(\mathrm{Ca})$, magnesium ( $\mathrm{Mg}$ ), assimilable phosphorus (ass. P) and potassium (K) were quantified prior to growth experiment. Height and collar diameter of seedling stems, final length and diameter of the main root were measured; the total dry biomass of root and shoot and, root to shoot ratio were evaluated for seedlings up to 5 months relating to the soil origin. Mean values of retained water and
\end{abstract}


selected nutrients were higher for mound soil than for surrounding soil. Besides, the studied parameters of $\mathrm{T}$. indica seedlings were significantly higher for mound soil than those recorded for surrounding soil $(\mathrm{P}<0.05)$ whereas seedlings of $\mathrm{B}$. aegyptiaca and $\mathrm{D}$. mespiliformis exhibited an increase final stem collar diameter and main root length on mound soil $(\mathrm{P}=0.039$ and 0.028 respectively). Root to shoot ratio of $\mathrm{B}$. aegyptiaca seedlings was positively correlated with great $\mathrm{N}$ content and that of $\mathrm{D}$. mespiliformis seedlings with great concentration of $\mathrm{Ca}$. Growth performance and adaptive traits of early seedlings of B. aegyptiaca, D. mespiliformis and T. indica were remarkable on M. subhyalinus mound soil compared to surrounding soil relating to the great level of soil fertility. Therefore, understanding the attitude of woody seedlings of local or exotic species is an important key in global plantation programs or assisting natural regeneration for biodiversity management and conservation.

Keywords: Burkina Faso, Multipurpose tree, Savanna regeneration, Seedling biomass, Soil macronutrients, Termitaria

\section{Introduction}

Heterogeneity in morphological features, growth and biomass production of woody species can be considered as cumulative outcomes of ecological processes that inherently vary in time and space (Lovett et al., 2005). This heterogeneity is more striking in African savannas as response to intensity gradient of these ecological processes which ultimately can positively or negatively impact the performance of woody species to colonize given ecosystems and/or the mechanisms that each species can develop to adapt to. Positive or negative impact of ecological processes can be expressed by selecting suite traits of species that control seedling establishment and thereby seedling recruitment into saplings, and later into mature trees in vegetation community (Solbrig, 1994). Among the ecological processes in arid and sub-arid savannas, soil processes and habitat modification are well known and documented as the major factors responsible of the availability and patchiness of environmental resources allocation locally redistributed which in return cause the mosaic dynamic, structure, composition and assemblage of woody species (Menaut et al., 1995). Environmental resources such as soil moisture, soil carbon $(\mathrm{C})$ and nutrient as nitrogen $(\mathrm{N})$, calcium $(\mathrm{Ca})$, potassium (K) magnesium (Mg), and assimilable phosphorus (ass. P) play a fundamental role in growth and development of the shoot and root systems of woody seedlings, and other biological processes thereby shape competitive interaction between species for colonizing various microhabitats (Ericsson, 1995; Taiz \& Zeiger, 2006; Chmelíková \& Hejcman, 2012; Gil et al. 2012; Tanoi \& Kobayashi, 2015). As consequent, sustained growth and efficient 
recruitment of seedling species, specific physiognomy of woody vegetation and by afar, biodiversity stability and resilience through propagation of stems of the same species are deeply correlated with optimal soil moisture and nutrient content in savanna ecosystems (Wiens, 1985; Bloom et al., 1985; Solbrig, 1994; Day et al., 2003; Clarke et al., 2005).

Microhabitats built by ecosystem engineers as Macrotermes sp workers as soil processes and habitat modification strongly alter the availability, patchiness and concentration of soil nutrients and stored water duration. In the course of their foraging and building activities, workers of Macrotermes subhyalinus Rambur (Termitidae, subfamily Macrotermitinae) directly or indirectly rearrange huge amounts of soil, in which they concentrate nutrient content deeply improved and stock in form of mounds above soil surface commonly considered as "heterogeneity drivers" (Holt \& Lepage, 2000; Moe et al., 2009; Jouquet et al., 2011; Muller \& Ward, 2013; Davies et al., 2016). Such fertile microhabitats scattered and available in savanna contribute to enhance safe ecological niches for plant species and for other organisms, and as rooting niche in where varied woody species occur, establish, develop and coexist for creating termite mound savanna despite species biogeographical origin as Sudanian, Guinea or Sahelian species and ecophysiological characteristics as fire sensitive species (Mobæk et al., 2005; Moe et al., 2009; Fandohan et al., 2012; Okullo \& Moe, 2012). Such microhabitats likely seem to provide fundamental attribute to seedlings of these woody species and then facilitate their establishment and recruitment into mature trees as specific response. By acting so, they may involve certain species to be favoured under different circumstances depending on the factors that can limit their morphology, productivity and, on the way of which these species can recover from and grow for becoming microhabitat indicators. This is the case of certain woody species hosted by termite mounds solely as indicatory flora including fire and herbivory sensitive or tolerance species or as annual or perennial species (Dossou-Yovo et al., 2009; Moe et al., 2009; Zida et al., 2009; van der Plas et al., 2013; Joseph et al., 2014). In parallel, woody species use to regenerate, survive and colonize disturbed or undisturbed microhabitats, and adapt to them through varied morphological and specific traits as vigorous root systems as net primary production. For example, woody species can increase their root biomass for escaping injurious of ecological interactions in savanna according to Zida et al. (2009) while they exhibit high relative growth rate as clue of sustained rapid growth of stem height in nutrient-rich habitat compared with nutrient-poor habitat (Chapin III, 1980). As regarding these previous results, the recruitment and survival of plants in field depend not solely on the top soil quality but mostly on the seedling quality such as stem and roots growth ability, biomass productivity during early seedling growth and the mechanisms they can use for taking root 
and recovering post disturbance. Works led by ecologists (Joseph et al., 2011; Jouquet et al., 2011; Muller \& Ward, 2013; Støen et al., 2013; Traoré et al., 2015) in various ecosystems showed that Macrotermes sp mounds hosting vegetation act for woody species as refuges under fire and livestock disturbances, water runoff events and, as regeneration facilitators due to their profile of elevated and fertile structures respectively. However, those discussing the ability of woody species and the mechanisms they use to become established, and grow to sapling and tree with emphasis on the attitude of seedlings on termite mounds in comparison with surrounding savanna in experimental designs are poorly or non-documented. It is in this optic that the present study was carried out for contributing to provide information on physiological attitude of wild multipurpose species that grow on epigeal termite mounds.

The objective of this work was to study whether woody species develop particular traits at seedling stage as feedback prior to establish, adapt to and grow on mounds of $M$. subhyalinus or not. To test this we quantified the growth performance of shoot system and the developed adaptive attributes of early seedlings in experimental pots using soil samples from $M$. subhyalinus mounds and surrounding area in a state forest. The results of growth assessment of early plants may improve our knowledge on the ability of viable propagules to establish on epigeal termite mounds and serve as guide in choosing species to introduce or assist natural regeneration in field for the target of biodiversity management and conservation considering given area characteristics as agroforestry or forestry. We specifically (1) compared moisture and nutrient content between soils of $M$. subhyalinus mound and corresponding surrounding area (as control); (2) assessed for each cohort on each site soil as growth features, the height and collar diameter of each stem and, the final length and diameter of the main root of each seedling as adaptive attribute; (3) examined the relationship between the total weight of dry biomass of root and shoot for each cohort and (4) tested whether the weight of dry root biomass over that of dry shoot biomass was related to the great soil nutrient content or not. Our findings could contribute to suggest another insight into the ability of certain woody species to be restricted to termite mounds or particular microsites although they are naturally growing in their ecological and geographical borders. We assumed that the growth performance and adaptive traits of early seedlings of Balanites aegyptiaca (L.) Del., Diospyros mespiliformis Hochst. Ex A.D.C. and Tamarindus indica L. are specific as feedback to $M$. subhyalinus mound in savanna ecosystems of which local residents depend on provided services and goods for their livelihood (von Maydell et al., 1990). 


\section{Materials and methods}

The study materials included seedlings of three multipurpose woody species of West African savanna ecosystems and soil samples collected on vegetated $M$. subhyalinus mounds and surrounding savanna in the sub-plots protected from prescribed fire regimen and livestock grazing settled in Tiogo state forest (Traoré et al., 2015). We focused on the soil of the large mounds occupied by the fungus-growing termite as M. subhyalinus due to its large influence on soil water infiltration, nutrient turnover, and on woody species assemblage in this ecosystem. The surrounding area or surrounding savanna in this study refers to the area being out of the visible influences of termite species such as foraging tunnel or sheeting.

\section{Study species description}

Species as Balanites aegyptiaca (L.) Del., Diospyros mespiliformis Hochst. Ex A.D.C. and Tamarindus indica L. involved in this study were selected among the numerous woody species identified on termite mound savanna (Traoré et al., 2008a, 2015; Erpenbach et al., 2014) to study the attitude of seedlings growing on $M$. subhyalinus mound in comparison with those growing in the surrounding savanna. B. aegyptiaca (Balanitaceae), a Sahelian species is drought and fire resistant and withstands up to 2 months flooding in areas near the river. It occurs on sandy clay loams, sandy loams or clays and prefers open woodland or savanna for natural regeneration.

D. mespiliformis (Ebenaceae), a Sudanian species prefers areas with permanent water that helps in natural regeneration. It favours heavy soils on riverbanks, in woodlands, savannahs and along riverbanks but also occurs in open woodland and is commonly found on termite mounds.

T. indica (Caesalpiniaceae), a Guinea species tolerates a range of soils but it prefers a well-drained, fertile soil. It occurs on coast and in sandy soils, on riverbanks, in savanna woodland, and is commonly related to termite mounds. $T$. indica seedlings and saplings are killed during fire event in savanna.

B. aegyptiaca, D. mespiliformis and $T$. indica are multipurpose tree species characterized by different ecological properties and are ecologically, socio-economically and socio-culturally used for ecosystem services and also as ecosystem goods respectively (von Maydell et al., 1990; Arbonnier 2000; Nikiéma 2005, Weber \& Montes, 2010; Orwa et al., 2009; Sanou et al. 2012; Aladi \& John, 2014). The natural populations of these woody species are experiencing higher pressure as consequences of increase demands as livestock overgrazing, fuel requirement, and extensive cultivation and the injurious effects of climate caprices (scarcity and abnormal seasonal distribution of rains) that cause a decline of the natural stands and regeneration. Recent reports have underlined that $M$. subhyalinus mounds shelter great density of mature trees and seedlings of these multipurpose 
species while the surrounding savanna solely shelters great density of juvenile stems of the same species (Abbadie et al., 1992; Traoré et al., 2015). The survival of seedlings and saplings was strongly reduced out of mounds due to the damage caused to them by abiotic and biotic factors during vulnerable stage in opened ecosystems.

\section{Sampling and properties of the study soils}

The soils used for plant growing were sampled in the Tiogo state forest located between $12^{\circ} 13^{\prime}-12^{\circ} 24^{\prime} \mathrm{N}$ and $2^{\circ} 42^{\prime}-2^{\circ} 52^{\prime} \mathrm{W}$, at an altitude of $300 \mathrm{~m}$ a.s.1., in the Centre West of Burkina Faso, West Africa. This state forest is characterized by ferruginous lixisols with deep silty-clay mainly $(>75 \mathrm{~cm}$ deep) according to Driessen et al. (2001). The main characteristics of the soil in this forest were clay $(24.8 \%)$, fine silt $(15.0 \%)$, coarse silt $(25.4 \%)$, fine sand $(21.7 \%)$, coarse sand $(13.1 \%)$, total organic matter $(1.8 \%)$, total nitrogen $(0.1 \%), \mathrm{C} / \mathrm{N}$ ratio $(11.4 \%)$, assimilable phosphorus $(1.4 \mathrm{ppm})$ and $\mathrm{pH}\left(\mathrm{H}_{2} \mathrm{O}\right)$ (6.2) (Sawadogo et al., 2005).

Soil bulks were directly sampled between 0 - $30 \mathrm{~cm}$ depth on moundtop, or dome, mound-slope and mound-base, and surrounding area (as control soil) as growth media in experimental quadrats described in Traoré et al. (2015).

Physical and chemical properties of each site soil were identified prior to set growth experiment. Soil moisture as soil water content was measured using soils sampled from mounds and surrounding area through two sampling methods in relation to the ability of seedlings to survive on each soil during their growth.

First method consisted to collect soil samples directly in the field during the rainy season in order to evaluate the variation of water storage duration. For this purpose, composite soil samples were taken with sterilised boxes three times at $\mathrm{t} 0, \mathrm{t} 1$ and $\mathrm{t} 2$ corresponding to 0 (rainy day), 2 and 4 days respectively after raining. The sampling operation was interrupted at a following rainy event.

Second method consisted to collect soil samples at fixed weight of $105 \mathrm{~g}$ after open air drying, with sterilised boxes and watered with fixed volume of $210 \mathrm{ml}$ each.

The fresh weight (FW) was measured for each soil samples according to sampling methods before drying them in oven at $105^{\circ} \mathrm{C}$ at constant weight for 4 days. The dry weight (DW) was then measured and water content (W) as soil relative moisture was calculated as a percentage of the dry soil weight using the following formula:

$$
W \%=\frac{(F W-D W)}{D W} * 100
$$


Chemical components were quantified at "Bureau National des Sols (BUNASOLS)" a national laboratory in charge of the physical and chemical analysis of soils in Burkina Faso. The amount of total organic C (TOC), and soil nutrient content such as total $\mathrm{N}(\mathrm{TN})$, and ass. $\mathrm{P}$ was quantified using the methods of Walkley \& Black (1948), Kjeldahl (1883) and Bray ${ }^{\circ} 1$ extractant respectively and $\mathrm{Ca}, \mathrm{K}, \mathrm{Mg}$ (Bunasols, 1987). Nutrients as $\mathrm{N}, \mathrm{Ca}, \mathrm{K}, \mathrm{Mg}$ and ass. $\mathrm{P}$ are provided solely by the soil or other growth media whereas $\mathrm{C}$ is obtained from water in which all nutrients are dissolved and available for plant roots uptaking in usable forms (Taiz \& Zeiger, 2006; Tanoi \& Kobayashi, 2015).

\section{Description of experimental design}

Soil bulks were crushed and mixed to constitute composite media, prior to fill perforated polythene black bags of $8 \mathrm{~cm} \times 15 \mathrm{~cm}$ sized, with a volume of 2 litres of soil samples of mound and that of surrounding area and kept in the nursery. Three replicates per species and per growth medium were performed. The filled bags referring to pots were used to conduct this study in order to ecologically harvest entire root and shoot systems even if broken for a good biomass quantifying contrary to in situ grown, seedlings cannot be harvested without digging soil and, many fine roots can be broken and left in the soil.

\section{Seedling emergence, growth and measurement}

Seedlings were obtained after germinating the seeds of B. aegyptiaca, D. mespiliformis and T. indica which were purchased from the National Centre of Forest Seeds (C.N.S.F), Burkina Faso. Maximum seeds were pre-treated with sulfuric acid $\left(\mathrm{H}_{2} \mathrm{SO}_{4}\right)$ of concentrated of $60 \%$ for 20 minutes for breaking all eventual dormancy in order to have the requested number of seedlings of the same age. Seeds were then rinsed and kept in beaker filled up with tap water for 72 hours. After pre-treating, two germinated seeds with the primary root were directly sowed at $3 \mathrm{~cm}$ of depth in each pot for early growth assessment. All the pots were deposited under partial tree shade in the cells of metallic frame to avoid all contact with soil surface and watered twice per day in the morning and evening during the whole experimental period for maintaining the soil moisture conditions.

The height and collar diameter of single stem and multi-stem individuals were monthly recorded 4 weeks after complete emergence of stems for each cohort. After 4 months of growth survey for D. mespiliformis and 5 months for $T$. indica and B. aegyptiaca, all the seedlings were then harvested and their roots were carefully washed to remove all soil particles. The survey was interrupted at 4 months for $D$. mespiliformis because the root system of seedlings was growing through the plastic bags. 
The final height and final collar diameter of each stem and, the length and diameter of the main root were recorded for each seedling species and growth medium. The measured root diameter corresponded to the average of three diameter values performed at the top, middle and tap-root because the main root of studied seedlings was showing varied width. Roots and shoots were separated and freshly weighted, dried in a hot-air oven for 2 days at $75^{\circ} \mathrm{C}$. After that the dry weight of roots and shoots were recorded respectively.

\section{Data analysis}

Graphical and statistical methods were used to explore and analyse recorded data for soil and seedlings. The growth curves were generated to assess the monthly variation of stem height and collar diameter for the cohorts of $B$. aegyptiaca, D. mespiliformis and $T$. indica for termite mound and surrounding soils.

The ratio of the weight of dry root biomass over dry shoot biomass was calculated for the total produced biomass for each cohort and each growth medium.

Univariate analysis (ANOVA) was performed to assess the effect of time, mound and their interactions on soil water content through method 1 on the one hand. Multiple comparison of mean values were carried out in case of significant effect. On the other hand Student's t-test was used to compare the mean values of water content in soil sampled through method 2. Student's ttest was also performed to compare between termite mound and surrounding soils the mean values of soil nutrient content, stem final height and collar diameter, root to shoot ratio within species (Underwood, 2002). Pearson's correlation was performed to examine relationship on the one hand between organic matter (TOC and TN) and nutrient content in each soil and, on the other hand between the weights of seedling dry biomass (root and/or shoot) and soil nutrient content.

All the statistical analysis were performed at $5 \%$ of significance with equal variances assumed using SPSS 20 for Windows.

\section{Results}

\section{Physical and chemical properties of the soil samples}

The results of physical and chemical properties of soil samples issue from M. subhyalinus mound and surrounding savannas are summarized and given in Table 1. The mean values of water content was higher for mound soil than surrounding soil through both of methods 1 and 2 . These values moderately decreased with time (method 1) while remaining higher for mound soil (Table 1).

The univariate analysis revealed no significant difference in stored water content over evaluation time and/or soil origin $(\mathrm{F}=0.749, \mathrm{P}=0.590)$ 
when method 1 was applied, and Student's t-test statistically also reported no difference in water content between termite mound and surrounding soils ( $\mathrm{P}>$ 0.05) (Table 1). Conversely, mound soil contained considerably percentages of $\mathrm{C}, \mathrm{N}, \mathrm{Ca}, \mathrm{K}, \mathrm{Mg}$ and ass. $\mathrm{P}$ in relation to surrounding soil ( $\mathrm{t}$-test, $\mathrm{P}<0.05$ ) whereas no statistical difference was observed for $\mathrm{C} / \mathrm{N}$ ratio between soil samples $(\mathrm{t}=0.69, \mathrm{P}=0.499)($ Table 1$)$.

Table 1. Comparison of mean values ( \pm standard deviation) of the amount of (A) stored water $\mathrm{W}$ and, (B) organic $\mathrm{C}$ and nutrients between $M$. subhyalinus mound and surrounding soils.

\begin{tabular}{|c|c|c|c|c|c|c|}
\hline & Mound soil & Surrounding soil & df & $F$ & $t$ & $P$ \\
\hline \multicolumn{7}{|c|}{ (A) Relative water content W (\%) } \\
\hline \multicolumn{7}{|c|}{ Method 1} \\
\hline Day 0 & $12.25 \pm 6.37$ & $10.05 \pm 6.46$ & & & & \\
\hline Day 2 & $10.76 \pm 5.66$ & $9.48 \pm 7.56$ & - & 0.749 & - & 0.59 \\
\hline Day 4 & $10.35 \pm 7.26$ & $9.46 \pm 7.04$ & & & & \\
\hline Method 2 & $19.33 \pm 3.92$ & $18.65 \pm 3.08$ & 33 & - & 0.56 & $\mathbf{0 . 3 3}$ \\
\hline \multicolumn{7}{|c|}{ (B) Chemical property } \\
\hline Total organic C $\%$ & $2.73 \pm 0.91 *$ & $1.54 \pm 0.94$ & 21 & - & 3.04 & 0.006 \\
\hline Total N \% & $0.22 \pm 0.08^{*}$ & $0.12 \pm 0.06$ & 21 & - & 3.50 & 0.002 \\
\hline $\mathrm{C} / \mathrm{N} \%$ & $12.98 \pm 2.15$ & $12.20 \pm 3.01$ & 21 & - & 0.69 & 0.499 \\
\hline $\mathrm{Ca}\left(\mathrm{Cmol} . \mathrm{Kg}^{-1}\right)$ & $11.51 \pm 4.06^{*}$ & $4.70 \pm 4.26$ & 21 & - & 3.88 & 0.001 \\
\hline $\mathrm{K}(\mathrm{ppm})$ & $1.41 \pm 0.56^{*}$ & $0.45 \pm 0.30$ & 21 & - & 5.10 & 0.0003 \\
\hline $\mathrm{Mg}\left(\mathrm{Cmol} \cdot \mathrm{Kg}^{-1}\right)$ & $4.26 \pm 1.33 *$ & $2.25 \pm 1.65$ & 21 & - & 3.16 & 0.005 \\
\hline Ass. P (ppm) & $6.62 \pm 2.95^{*}$ & $1.98 \pm 1.55$ & 21 & - & 4.90 & 0.0001 \\
\hline
\end{tabular}

* Significant at $P<0.05$ with equal variances assumed

The analysis of Pearson's correlation showed positive relationship between soil nutrient and TOC, TN percentage as has been shown in Table 2. The great amount of $\mathrm{Ca}$ was highly correlated with the great percentage of TOC ( $\mathrm{P}<0.001)$, and $\mathrm{Mg}$ content was strongly correlated with the great percentage of TOC and TN $(\mathrm{P}<0.05)$ in mound soil; Pearson's correlation was highly significant between ass. $\mathrm{P}$ and $\mathrm{Ca}$ contents in mound soil $(\mathrm{P}<$ $0.001)$ and weakly in surrounding soil $(\mathrm{P}<0.05)$. At the opposite side, the amount of soil $\mathrm{Ca}(\mathrm{P}<0.001)$ and, $\mathrm{Mg}$ and ass. $\mathrm{P}(\mathrm{P}<0.05)$ were significantly related with $\mathrm{TOC}$ and $\mathrm{TN}, \mathrm{Mg}$ and ass. $\mathrm{P}$ content were correlated with $\mathrm{Ca}$ content in the surrounding soil samples (Table 2). 
Table 2. Variation of the coefficient value of Pearson's correlation between the amount of, TOC and nutrient contents for the soils of (A) M. subhyalinus mound and (B) surrounding area.

\begin{tabular}{|c|c|c|c|c|c|c|c|}
\hline & $\mathrm{TN} \%$ & TOC $\%$ & $\mathrm{C} / \mathrm{N} \%$ & $\begin{array}{c}\mathrm{Ca} \\
\left(\mathrm{Cmol} . \mathrm{Kg}^{-1}\right) \\
\end{array}$ & $\begin{array}{c}\mathrm{Mg} \\
\left(\mathrm{Cmol} \cdot \mathrm{Kg}^{-1}\right)\end{array}$ & $\begin{array}{l}\text { ass. P } \\
\text { (ppm) }\end{array}$ & $\begin{array}{c}\mathrm{K} \\
(\mathrm{ppm})\end{array}$ \\
\hline \multicolumn{8}{|c|}{ (A) Mound soil } \\
\hline $\mathrm{TN} \%$ & 1 & & & & & & \\
\hline TOC \% & $0.857^{* *}$ & 1 & & & & & \\
\hline $\mathrm{C} / \mathrm{N} \%$ & -0.530 & -0.050 & 1 & & & & \\
\hline $\mathrm{Ca}\left(\mathrm{Cmol} . \mathrm{Kg}^{-1}\right)$ & 0.531 & $0.702^{* *}$ & 0.005 & 1 & & & \\
\hline $\operatorname{Mg}\left(\mathrm{Cmol} . \mathrm{Kg}^{-1}\right)$ & $0.850^{* *}$ & $0.936^{* *}$ & -0.097 & 0.528 & 1 & & \\
\hline ass. P (ppm) & 0.130 & 0.496 & 0.415 & $0.834^{* *}$ & 0.334 & 1 & \\
\hline $\mathrm{K}(\mathrm{ppm})$ & -0.439 & -0.440 & 0.189 & -0.062 & -0.549 & 0.083 & 1 \\
\hline \multicolumn{8}{|c|}{ (B) Surrounding soil } \\
\hline $\mathrm{TN} \%$ & 1 & & & & & & \\
\hline TOC \% & $0.980^{*}$ & 1 & & & & & \\
\hline $\mathrm{C} / \mathrm{N} \%$ & $0.580^{*}$ & $0.725^{* *}$ & 1 & & & & \\
\hline $\mathrm{Ca}\left(\mathrm{Cmol} \cdot \mathrm{Kg}^{-1}\right)$ & $0.852^{* *}$ & $0.803^{* *}$ & 0.370 & 1 & & & \\
\hline $\operatorname{Mg}\left(\mathrm{Cmol} \cdot \mathrm{Kg}^{-1}\right)$ & $0.982^{*}$ & $0.962^{*}$ & $0.561^{*}$ & $0.884^{*}$ & 1 & & \\
\hline ass. $\mathrm{P}$ (ppm) & $0.838^{*}$ & $0.873^{*}$ & $0.681^{*}$ & $0.604^{*}$ & $0.826^{*}$ & 1 & \\
\hline $\mathrm{K}(\mathrm{ppm})$ & -0.198 & -0.072 & 0.471 & -0.199 & -0.133 & -0.256 & 1 \\
\hline
\end{tabular}

\section{Growth performance of seedlings}

The Figure 1 based on the monthly measurement presents the variation of seedling height and collar diameter within species and over time. Height and collar diameter of stem of the cohort per species were unequally distributed during the survey periods and according to growth soil origin. Conversely, within species, the monthly mean value of stem height and collar diameter of $B$. aegyptiaca and $T$. indica seedlings constantly increased for termite mound soil compared with surrounding soil whereas stem height and collar diameter of $D$. mespiliformis seedlings increased solely on surrounding soil (Figure 1).

Moreover, the values of monthly rate of relative growth of stem height and collar diameter of the seedling cohorts varied remarkably in response to soil origin during the survey period. Great value was observed for seedlings height of B. aegyptiaca (51.27\%) and diameter of B. aegyptiaca $(40.47 \%)$ and $T$. indica $(39.71 \%$ ) seedlings on mound soil (Table 3$)$. For B. aegyptiaca seedlings the growth rate of stem height on mound soil was 1.35 and 1.17 times those recorded on surrounding soil at the first 2 and last months of survey and, the collar diameter was threefold and 6 times at the same period. 
As showed in Table 3, an increasing in stem height was observed for D. mespiliformis seedlings solely on mound soil at the first two months $(32.84$ $\%$ ) while the collar diameter constantly increased on surrounding soil. Increase values of relative growth rate of stem height was observed for the seedlings of B. aegyptiaca, D. mespiliformis and T. indica (except for surrounding soil) at the end of survey meaning a remarkable growth of stem height with suit
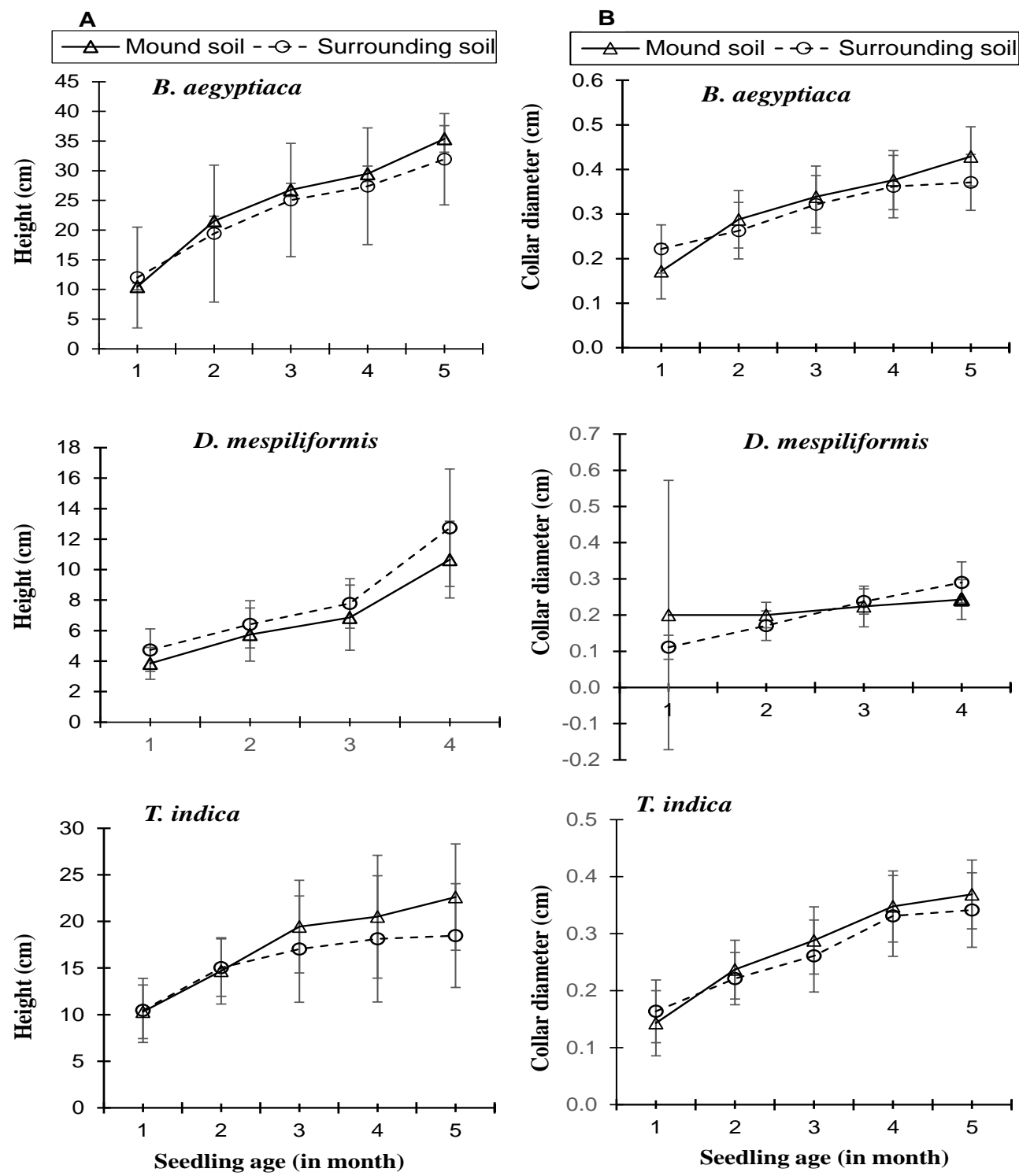

Figure 1. Distribution of mean values ( \pm standard deviation) of height (A) and collar diameter (B) of tree seedlings growing on the M. subhyalinus mound soil and surrounding soil. 
Table 3: Variation of the monthly rate of relative growth of the stem height and collar diameter of seedlings per species on the M. subhyalinus mound and surrounding soils.

\begin{tabular}{|c|c|c|c|c|c|c|c|c|c|}
\hline \multirow[b]{3}{*}{ Seedling species } & \multirow[b]{3}{*}{ Soil origin } & \multicolumn{4}{|c|}{ Stem height (\%) } & \multicolumn{4}{|c|}{ Stem collar diameter $\%$} \\
\hline & & \multicolumn{4}{|c|}{ Seedling age (in months) } & \multicolumn{4}{|c|}{ Seedling age (in months) } \\
\hline & & 2 & 3 & 4 & 5 & 2 & 3 & 4 & 5 \\
\hline \multirow{2}{*}{ Balanites aegyptiaca } & Mound soil & 51.27 & 19.61 & 9.20 & 16.67 & 40.47 & 15.01 & 9.88 & 12.36 \\
\hline & Surrounding soil & 38.11 & 22.56 & 8.51 & 14.23 & 15.55 & 18.27 & 11.14 & 2.13 \\
\hline Diospyros & Mound soil & 32.84 & 16.28 & 35.7 & - & 0 & 10.59 & 7.89 & - \\
\hline mespiliformis & Surrounding soil & 26.32 & 17.64 & 38.97 & - & 34.92 & 28.05 & 18.18 & - \\
\hline \multirow{2}{*}{ Tamarindus indica } & Mound soil & 29.81 & 24.41 & 5.17 & 9.29 & 39.71 & 17.77 & 17.14 & 5.72 \\
\hline & Surrounding soil & 30.52 & 11.66 & 6.06 & 1.89 & 25.91 & 15.21 & 21.25 & 3.02 \\
\hline
\end{tabular}

Student's t test revealed that the final values of height and collar diameter of stem, the length and diameter of the main root of $\mathrm{T}$. indica seedlings were significantly higher for mound soil than surrounding soil $(\mathrm{P}<$ 0.05) (Table 4). The mean values of the final collar diameter of stem of B. aegyptiaca seedlings growing on mound soil significantly increased $(\mathrm{P}=$ 0.039) while D. mespiliformis seedlings exhibited significant long main root on mound soil $(\mathrm{P}=0.028)$ as compared with those growing on surrounding soil.

According to the values of root to shoot ratio in Table 4, the weight of seedling dry roots were equivalent to $1.69,1.07$ and 1.41 the weight of dry shoot system on mound soil for B. aegyptiaca, D. mespiliformis and T. indica respectively. But no significant difference in the ratio value of dry root over dry shoot biomass between soils ( $\mathrm{t}$-test, $\mathrm{P}>0.05)$ indicating similar ratio values.

The correlation analysis of Person showed that the ratio value of dry root over dry shoot biomass of D. mespiliformis seedlings was positively correlated with the great amount of $\mathrm{Ca}$ contained in both of mound and surrounding soils (mound soil, coefficient $=0.999 ; \mathrm{P}=0.024$ and surrounding soil, coefficient $=0.998 ; \mathrm{P}=0.031$ ) whereas the ratio value of dry root to dry shoot biomass of B. aegyptiaca seedlings was significantly correlated with the great amount of TN of mound soil only (coefficient $=0.980 ; \mathrm{P}=0.020$ ).

More, the root systems of seedlings of B. aegyptiaca, D. mespiliformis and $\mathrm{T}$. indica growing on $\mathrm{M}$. subhyalinus mound soil showed countless fine roots or root hairs in comparison with those of seedlings on surrounding soil (Figure 2). But the root system of seedlings of T. indica was more ramified growing on mound soil comparatively with that of seedlings of the same species on surrounding soil. 
Table 4: Variation of the mean values ( \pm standard deviation) of the final stem height, collar diameter, main root length and diameter and root to shoot ratio of the dry biomass weight of seedling cohorts for each species growing on the M. subhyalinus mound soil and surrounding soil.

\begin{tabular}{|c|c|c|c|c|c|c|c|c|c|}
\hline \multirow[b]{2}{*}{ Seedling parameters } & \multicolumn{3}{|c|}{ Balanites aegyptiaca } & \multicolumn{3}{|c|}{ Diospyros mespiliformis } & \multicolumn{3}{|c|}{ Tamarindus indica } \\
\hline & Mound & Surrounding & $P$ & Mound & Surrounding & $P$ & Mound & Surrounding & $P$ \\
\hline Final stem height $(\mathrm{cm})$ & $35.38 \pm 11.18$ & $31.94 \pm 7.69$ & 0.41 & $10.66 \pm 2.51$ & $12.75 \pm 3.85$ & 0.93 & $22.61 \pm 5.70 *$ & $18.48 \pm 5.56$ & 0.005 \\
\hline Final collar diameter $(\mathrm{cm})$ & $0.43 \pm 0.07 *$ & $0.37 \pm 0.06$ & 0.039 & $0.24 \pm 0.06$ & $0.29 \pm 0.06$ & 0.48 & $0.37 \pm 0.06^{*}$ & $0.34 \pm 0.07$ & 0.0001 \\
\hline Main root length $(\mathrm{cm})$ & $28.52 \pm 10.37$ & $24.93 \pm 8.65$ & 0.056 & $36.79 \pm 14.68 *$ & $26.90 \pm 12.65$ & 0.028 & $41.55 \pm 15.65^{*}$ & $32.88 \pm 13.61$ & 0.001 \\
\hline Main root diameter $(\mathrm{cm})$ & $0.30 \pm 0.07$ & $0.27 \pm 0.07$ & 0.93 & $0.22 \pm 0.11$ & $0.23 \pm 0.12$ & 0.67 & $0.27 \pm 0.06^{*}$ & $0.22 \pm 0.06$ & 0.0007 \\
\hline Root-shoot ratio & $1.69 \pm 1.13$ & $1.38 \pm 1.03$ & 0.47 & $1.07 \pm 0.89$ & $0.33 \pm 0.21$ & 0.52 & $1.41 \pm 0.75$ & $1.31 \pm 0.54$ & 0.744 \\
\hline
\end{tabular}

* Significant at $P<0.05$ with equal variances assumed; $P$ : Probability 


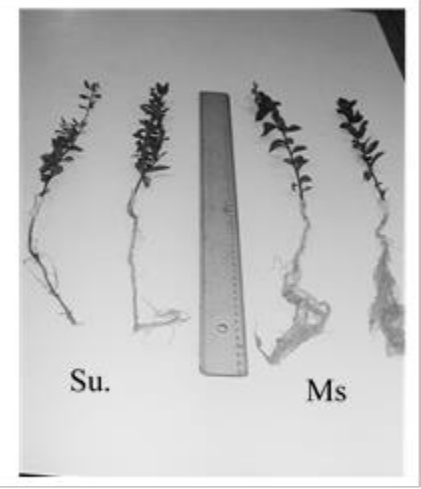

1. Balanites aegyptiaca

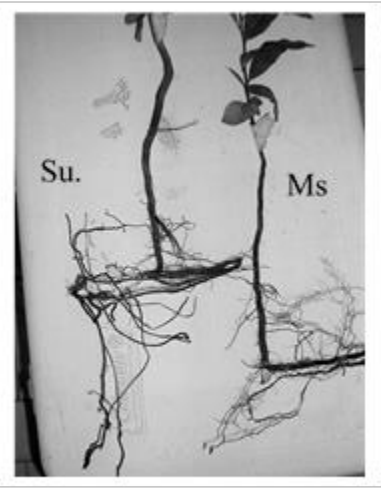

2. Diospyros mespiliformis

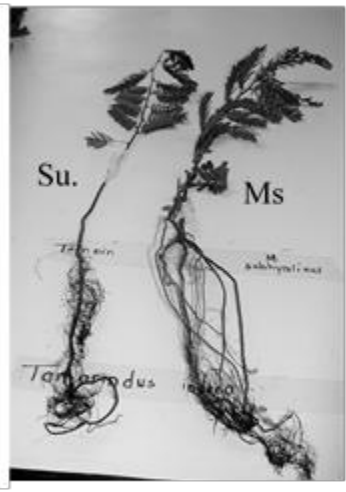

3. Tamarindus indica

Figure 2: Comparison of the seedlings resulting from the soil of Macrotermes subhyalinus mound (Ms) and surrounding soil (Su.)

\section{Discussion}

The present study quantified and compared the growth performance and adaptive strategies of early seedlings of B. aegyptiaca, D. mespiliformis and $\mathrm{T}$. indica through their morphology and biomass production using $\mathrm{M}$. subhyalinus mound soil in order to understand whether woody species develop particular traits at seedling stage as feedback prior to establish and colonize epigeal termite mounds. Changes were observed for seedling cohort of each species which changes tend to be as specific feedback to M. subhyalinus modulated soil in comparison with "intact" soil collected from the surrounding area. Although the absence of significant difference in water content between growth soil samples, the mean values of stored water content remains higher for M. subhyalinus mound soil as compared with surrounding soil along the time spectrum. This likely may be due to the general structure of soil in Tiogo forest which has influenced water content of study soil samples at soil level and time level as regarding the great values of the standard deviations. The great percentage of soil stored water may be explained by the predominance of finer sized particles used for mound building and also found in the original savanna soil in Tiogo forest (Sawadogo et al., 2005; Pallo et al., 2009; Traoré et al. 2015). On contrary to water content which is statistically similar, mound soil contained significant great amounts of TOC, TN and nutrients as $\mathrm{Ca}, \mathrm{K}$, $\mathrm{Mg}$ and ass. P. Nutrient concentration also increase with that of TOC and TN according to Pearson's correlation test. The amount of TOC and TN may result from termite wastes combined with great organic matters resulting from dead termites and other dead organisms such as hedgehog, rodent, gecko that seem to be accumulated in mound cavities and from fallen leaves and decayed roots (as litter layer) of plants growing in mound savanna (Traoré et al., 2015) whereas the release nutrients may result from soil microbial activities as 
reported by Duponnois et al. (2005). As they accumulate in soil, $\mathrm{C}$ and $\mathrm{N}$ act as traps for nutrients and by this way they retain nutrient in form of salts in soil and thereby increase mound fertility at low cost. Consequently, the higher the percentage of TOC and $\mathrm{TN}$ in the soil, the higher the nutrient concentration. The positive association that exists between nutrients and, TOC and $\mathrm{TN}$ justify the fact that $\mathrm{M}$. subhyalinus mounds are considered as small macronutrients reservoirs or "hot-spots" macronutrients (Holt \& Lepage, 2000) scattered in savanna ecosystems. These small reservoirs of macronutrients play key role in the functioning and pattern of plant communities during succession steps from pioneers to climax.

The studied parameters of $\mathrm{T}$. indica seedlings except the dry biomass of root/shoot, stem collar diameter of B. aegyptiaca and the length of main root of D. mespiliformis seedlings significantly increased on soil samples of termite mound. The great value of monthly relative growth rate indicate rapidly increase for each species cohort on mound soil at the beginning of measurement. Increase of these morphological traits of seedlings on mound soil may certainly be due to a constant production of new body tissues further to regular uptake of great nutrient content available in the usable forms and stimulated by long main root and numerous associated fines roots that seedlings developed during their growth (Taiz \& Zeiger, 2006). Such fines roots seems to have increased the root surface of absorption and therefore, strengthen seedling proficiency to acquire soil water and nutrients on mounds for maximizing seedling growth or promoting their regrowth after drought injurious according to Bloom et al. (1985). Contrary to surrounding soil, fine root proliferation and root growth of seedlings were reduced relating to weak nutrient availability.

No significant difference was observed in the values of root to shoot ratio in relation to growth soil origin indicating that the study species have similar weight of dry roots over dry shoots wherever they can grow. Nevertheless, the weight of dry root slightly exceeds that of dry shoot biomass of seedlings leading to consider that seedling species belong to the same biological life growth form as woody or perennial species of which the values root to shoot ratio are specific. Work carried out by Monk (1969) on the relationship between above and underground parts of 15 plant species reported that the higher values of root to shoot ratio (root/shoot $>1$ ) are considered as indicators of perennial woody and plant species adapted to dry site.

The present results corroborate previous reports on the relationship between plants and their growth site. It seems that when soil nutrients get lower as observed for soil from surrounding savanna, the growth of plant species get reduce or interrupt. Therefore, seedlings to a certain extent juvenile plants get to adapt their demands for nutrients in response to a decline of soil solution caused by drought stress. Throughout establishment, the great rate of 
relative growth of $\mathrm{T}$. indica seedlings and the long root of $\mathrm{D}$. mespiliformis can ensure for them a competitive benefit when seedlings of these species are grown together with other plant species in the diversified microhabitats (high species diversity) as mounds of M. subhyalinus (Joseph et al., 2014; Davies et al., 2016) or microhabitats presenting similar physical and chemical properties. The development of the collar diameter subsequently the root system seems primordial for the study woody species to anchor and stock mineral resources for escaping damage when environmental conditions and soil moisture are suitable.

Regarding the increase size of aerial and underground systems during early growth of seedlings of B. aegyptiaca, D. mespiliformis and T. indica in experimental design, we may certify that the proliferation of fine roots, maximizing root growth, and root biomass may constitute the adaptive strategies for seedlings as feedback to mound soil quality. Moreover, recruitment of seedlings into saplings and mature individuals may be interrelated to the constant increase of stem height and collar diameter as suit growth performance for most woody species growing on large termite mounds or some particular microhabitats else.

\section{Conclusion}

According to our results, there is evidence that early seedlings of B. aegyptiaca, D. mespiliformis and T. indica or other woody species have a good growth performance while develop particular traits as feedback prior to establish and grow on M. subhyalinus mounds as compared with the surrounding soil and so, in relation to TOC and soil nutrient content in mounds. The survey of the growth and development of seedlings of similar age of B. aegyptiaca, D. mespiliformis and T. indica showed a progressive increase of stem height and collar diameter that indicate suitable growth performance on $\mathrm{M}$. subhyalinus mound soil samples as advantageous for seedlings to escape intra- and/or interspecific competition events and environmental factors injurious in savanna ecosystems. The present study showed that most woody species can adapt their morphology and functioning, and develop strategies to survive, coexist, and grow for becoming indicators of termite mounds. By this way they thereby generate a nutrient-rich savanna to the detriment of the less competitive species although they are growing in or outside their geographical borders. For this reason, understanding the attitude of woody seedling of local and/or exotic species is an important key for their domestication or assisting natural regeneration at small or large scale in ecosystem restoration and, biodiversity management and conservation regarding the given microhabitat characteristics as rooting niches. 


\section{Funding}

Financial support had been provided by Swedish International Development Cooperation Agency/Swedish Agency for Research Cooperation with Developing Countries (Sida / SAREC) through the "Ecosystem regeneration" Université Joseph KI-ZEBO (formely Université de Ouagadougou) and INERA, Burkina Faso, research project from 2002 to 2008 and Unité de Recherches (UR) 179 « SéqBio» IRD, for soil analysis.

\section{Acknowledgements}

We are grateful to Professor Edmond Hien, soil scientist and Joseph Sawadogo (PhD), UFR-ST, Université Nazi Boni, for editing this manuscript, to Mulualem Tigabu, SSFRC/FFS/ SLU, Alnarp, Sweden, to Samadou Coulibaly for English proofreading and to the anonymous reviewers and editors for their valuables comments and suggestions.

\section{References:}

1. Abbadie L., Lepage M. \& Le Roux X. (1992). Soil fauna at the forestsavanna boundary: role of termite mounds in nutrient cycling. In Furley PA, Proctor J, Ratter JA (eds) Nature and dynamics of forestsavanna boundaries, Chapman \& Hall, pp 473-484.

2. Aladi S F. \& John O. O. (2014). Farmer's perception of opportunities preferences and obstacles of growing multipurpose trees on farmland in Kogi state. European Scientific Journal 10, 1857-7881.

3. Arbonnier M. (2000). Arbres, Arbustes et Lianes des Zones Sèches de l'Afrique de l'Ouest. CIRAD, MNHN, UICN, Montpellier, France.

4. Bloom A. J., Chapin III F. S. \& Mooney H. A. (1985). Resource limitation in plants an economic analogy. Annual Review of Ecology and Systematics 16, 363-92.

5. Chapin III FS (1980). The mineral nutrition of wild plants. Annual Review of Ecology and Systematics 11, 233-260.

6. Chmelíková L. \& Hejcman M. (2012). Effect of nitrogen, phosphorus and potassium availability on emergence, nodulation and growth of acidicole Trifolium arvense L. in alkaline soil. Flora 207, 805-811

7. Clarke L. W., Li L., Jenerette G. D. \& Yu Z. (2014). Drivers of plant biodiversity and ecosystem service production in home gardens across the Beijing Municipality of China. Urban Ecosystem, 17, 741-760.

8. Davies A. B., Baldeck C. A. \& Asner G. P. (2016). Termite mounds alter the spatial distribution of African savanna tree species. Journal of Biogeography 43, 301-313.

9. Day K. J., Hutchings M. J. \& John E. A. (2003). The effects of spatial pattern of nutrient supply on the early stages of growth in plant populations. Journal of Ecology 91, 305-315. 
10. Dossou-Yovo H. O., Assogbadjo A. E. \& Sinsin B. (2016). The contribution of termitaria to plant species conservation in the Pendjari Biosphere Reserve in Benin. Environment and Ecology Research 4, 200-206.

11. Driessen P., Deckers J. \& Spaargaren O. (2001). Lecture notes on the major soils of the world. FAO World Soil Resources Reports 94. Food and Agriculture Organization of the United Nations, Rome, $307 \mathrm{pp}$.

12. Duponnois R., Paugy M., Thioulouse J., Masse D. \& Lepage M. (2005). Functional diversity of soil microbial community, rock phosphate dissolution and growth of Acacia seyal as influenced by grass-, litter- and soil-feeding termite nest structure amendments. Geoderma, 124: 349-361.

13. Ericsson T. (1995). Growth and shoot: root ratio of seedlings in relation to nutrient availability. Plant Soil 168-169, 205-214.

14. Erpenbach A., Wittig R. \& Karen H. (2014). Dynamics of juvenile woody plant communities on termite mounds in a West African savanna landscape. Flora et Vegetatio Sudano-Sambesica 17, 28-41.

15. Fandohan B., Assogbadjo A.E., Salako V.K., van Damme P. \& Sinsin B. (2012). Which one comes first, the tamarind or the Macrotermes termitarium? Acta Botanica Gallica 159, 345-355.

16. Gil P. M., Bonomelli C., Schaffer B., Ferreyra R. \& Gentina C. (2012). Effect of soil water-to-air ratio on biomass and mineral nutrition of avocado trees. Journal of Soil Science and Plant Nutrition 12, 609-630.

17. Holt J. A. \& Lepage M. (2000). Termites and soil properties. In: Abe T, Bignell D. E., Higashi M (Eds.), Termites: evolution, sociality, symbioses, ecology. Kluwer Academic Publishers, Dordrecht, pp: 389-407.

18. Joseph G. S., Cumming G. S., Cumming D. H. M., Mahlangu Z., Altwegg R. \& Seymour C. L. (2011). Large termitaria act as refugia for tall trees, deadwood and cavity-using birds in a Miombo woodland. Landscape. Ecology 26, 439-448.

19. Joseph G. S., Seymour C. L., Cumming G. S., Cumming D. H. M. \& Mahlangu Z. (2014). Termite mounds increase functional diversity of woody plants in African savannas. Ecosystems 17, 808-819.

20. Jouquet P., Traoré S., Choosai C., Hartmann C. \& Bignell D. (2011). Influence of termites on ecosystem functioning. Ecosystem services provided by termites. European Journal of Soil Biology 47, 215-222.

21. Lovett G. M., Jones C. G., Turner M. G., Weathers K. C. (Eds.), 2005. Ecosystem function in heterogeneous landscapes, New York.

22. Menaut J.C., Lepage M. \& Abbadie L. (1995). Savannas, woodlands and dry forests in Africa. In: Bullock S. H., Mooney H. A. \& Medina 
E. (Eds.) Seasonally dry tropical forests, Cambridge University Press, Cambridge, pp. 64-92.

23. Mobæk R., Narmo A. K. \& Moe S. R. (2005). Termitaria are focal feeding sites for large ungulates in Lake Mburo National Park, Uganda. Journal of Zoology London, 267, 97-102.

24. Moe S. R., Mobæk R. \& Narmo A. K. (2009). Mound building termites contribute to savanna vegetation heterogeneity. Plant Ecology 202, 3140.

25. Monk C. (1966). Ecological importance of root/shoot ratios. Bulletin of Torrey Botanical Club 6, 402-406.

26. Muller K. \& Ward D. (2013). Direct and indirect effects of termites on savanna tree-seedling growth. Plant and Soil 214, 811-819.

27. Nikiéma A. (2005). Agroforestry parkland species diversity: Uses and management in semi-arid West Africa (Burkina Faso). PhD thesis, Wageningen University

28. Okullo P. \& Moe S. R. (2012). Termite activity, not grazing, is the main determinant of spatial variation in savanna herbaceous vegetation. Journal of Ecology 100, 232-241

29. Orwa C., Mutua A., Kindt R., Jamnadass R. \& Anthony J. S. (2009). Agroforestree Database: a tree reference and selection guide version 4.0 (http://www.worldagroforestry.org/sites/treedbs/treedatabases.asp).

30. Pallo F. J. P., Sawadogo N., Zombré N. P. \& Sedogo M. P. (2009). Statut de la matière organique des sols de la zone nord-soudanienne au Burkina Faso. Biotechnologie, Agronomie, Société et Environnement 13, 139-142.

31. Sanou J., Bayala J., Teklehaimanot Z. \& Bazié P. (2012). Effect of shading by baobab (Adansonia digitata) and néré (Parkia biglobosa) on yields of millet (Pennisetum glaucum) and taro (Colocasia esculenta) in parkland systems in Burkina Faso, West Africa. Agroforest Systems 85, 431-441.

32. Sawadogo L., Tiveau D. \& Nygård R. (2005). Influence of selective tree cutting, livestock and prescribed fire on herbaceous biomass in the savannah woodlands of Burkina Faso, West Africa. Agriculture, Ecosystems and Environment 105, 335-345.

33. Solbrig O. T (1994). Plant traits and adaptive strategies: their role in ecosystem function. Ernst-Detlef Schulze \& Harold A. Mooney (Eds.) Biodiversity and savanna ecosystem processes. Ecological studies, 121. Springer-Verlag, Berlin Heidelberg New York.

34. Støen O. G., Okullo P., Eid T. \& Moe S. R. (2013). Termites facilitate and ungulates limit savanna tree regeneration. Oecologia 172, 10851093. 
35. Taiz L. \& Zeiger E. (2006). Plant Physiology. 4e ed.

36. Tanoi K. \& Kobayashi N. I. (2015). Leaf senescence by magnesium deficiency. Plants 4, 756-772.

37. Traoré S., Nygård R., Guinko S. \& Lepage M. (2008a). Impact of Macrotermes termitaria as a source of heterogeneity on tree diversity and structure in a Sudanian savannah under controlled grazing and annual prescribed fire (Burkina Faso). Forest Ecology and Management 255, 2337-2346.

38. Traoré S., Tigabu M., Ouédraogo J. S., Boussim J. I., Guinko S. \& Lepage M. (2008b). Macrotermes mounds as sites for tree regeneration in a Sudanian woodland (Burkina Faso). Plant Ecology 198, 285-295.

39. Traoré S., Tigabu M., Jouquet P., Ouédraogo J S., Guinko S. \& Lepage M. (2015). Long-term effects of Macrotermes termites, herbivores and annual early fire on woody undergrowth community in Sudanian woodland, Burkina Faso. Flora 211, 40-50.

40. Underwood A. J. (2002). Experiments in ecology: Their logical design and interpretation using analysis of variance. University Press, Cambridge, UK.

41. van der Plas F., Howison R., Reinders J., Fokkema W. \& Olff H. (2013). Functional traits of trees on and off termite mounds: Understanding the origin of biotically-driven heterogeneity in savannas. Journal of Vegetation Science 24, 227-238.

42. von Maydell H. J. \& Brase J. (1990). Trees and shrubs of the Sahel. Their characteristics and uses. Margraf.

43. Walkley A. \& Black I. A. (1934). An examination of the Degtjareff method for determining soil organic matter and a proposed modification of the chromic acid titration method. Soil Sci., 37, 29-38

44. Weber J. C. \& Montes C. S. (2010). Correlations and clines in tree growth and wood density of Balanites aegyptiaca (L.) Delile provenances in Niger. New Forests 39, 39-49.

45. Wiens J. A. (1985). Vertebrate responses to environmental patchiness in arid and semi-arid ecosystems. In: Pickett S. T. A. \& White P. S. (Eds.), The ecology of natural distance and patch dynamics. Academic Press, London. pp. 153-168.

46. Zida D., Tigabu M., Sawadogo L., Tiveau D., Odén, P.C. (2009). Long-term effects of prescribed early fire, grazing and selective tree cutting on seedling populations in the Sudanian savanna of Burkina Faso. African Journal of Ecology 47, 97-108. 